\title{
A case benign struma ovarii
}

\section{P. G. Paul*, Anjana Annal, K. Anusha Chowdary, George Paul, Manali Shilotri}

Department of Gynec Endoscopy and Infertility, Paul's Hospital, Kochi, Kerala, India

Received: 14 January 2021

Accepted: 11 February 2021

\section{*Correspondence:}

Dr. P. G. Paul,

E-mail: drpaulpg@gmail.com

Copyright: () the author(s), publisher and licensee Medip Academy. This is an open-access article distributed under the terms of the Creative Commons Attribution Non-Commercial License, which permits unrestricted non-commercial use, distribution, and reproduction in any medium, provided the original work is properly cited.

\begin{abstract}
Struma ovarii is a rare ovarian tumor and a monodermal variant of dermoid tumors of the ovary in which thyroid tissue components constitute more than $50 \%$ of the mass. Struma ovarii accounts for $0.5-1.0 \%$ of all ovarian tumors and $2-5 \%$ of ovarian teratomas. Most cases are benign, but malignant transformation is found in a small percentage. It usually presents as a unilateral adnexal mass at fifth and sixth decades of life, with symptoms like other ovarian tumors. The definitive diagnosis is made by histological examination. Adnexectomy remains the standard line of treatment for benign disease. A 41-year-old lady presented with pain in abdomen for 3 months. On ultrasonography and MRI, a multiloculated solid cystic lesion of $7 \times 6 \mathrm{~cm}$ with internal echoes was found in the right adnexa. Laparoscopic right adnexectomy was performed. Histopathology was consistent with struma ovarii. Due to its vague clinical manifestations and diverse imaging characteristics, pre-operative diagnosis is challenging.
\end{abstract}

Keywords: Struma ovarii, Ovarian thyroid, Adnexectomy

\section{INTRODUCTION}

Struma ovarii is a monodermal variant of ovarian dermoid tumors, in which the component of thyroid tissue constitutes more than $50 \%$ of the mass. ${ }^{1}$ Struma ovarii may rarely be found with serous or mucinous cystadenomas. Struma ovarii comprises only $0.5 \%-1.0 \%$ of all ovarian tumors and $2-5 \%$ of ovarian teratomas. ${ }^{2}$ Majority of them are benign, but malignancy is found in $0.3 \%$ of cases, and malignant transformation occurs in $5 \%{ }^{3,4}$ The presenting symptoms are similar to other ovarian tumors. They generally occur in women in the fifth and sixth decades of life. They are usually unilateral and mostly on the left side. ${ }^{1,2}$ The final diagnosis is made by histopathological examination.

\section{CASE REPORT}

A 41-year-old, para one woman, presented with pain abdomen for three month's duration. She was on treatment for hypothyroidism for three years. She underwent an FNAC for a lump in the right breast, which was normal. Her menstrual cycle was regular with dysmenorrhoea. She had undergone one caesarean section 15 years back. On examination, a cystic mass of 12 weeks pregnant uterus size was noted. On ultrasonography, a multiloculated cystic lesion of $7 \times 6 \mathrm{~cm}$ with internal echoes, with a solid area of $1.3 \mathrm{~cm}$ in one loculus was seen in the right adnexa. Right ovary was not seen separately (Figure 1). MRI showed a similar picture of multiloculated cystic lesion in right adnexa with few solid projections, thin internal septations, and right ovary was not seen separately (Figure 1). Tumour markers were as follows - Ca 125 - $11 \mathrm{U} / \mathrm{ml}$, CEA $2.4 \mathrm{ng} / \mathrm{ml}, \mathrm{CA} 19.9$ $28.9 \mathrm{U} / \mathrm{ml}$

She was planned for laparoscopic right adnexectomy. Laparoscopy showed an enlarged right ovary with a $7 \mathrm{~cm}$ multiloculated cyst and adnexectomy was performed (Figure 2). The specimen was removed in an endobag. Grossly, the cyst was $7 \mathrm{~cm}$ in size, multiloculated with multiple tiny yellowish nodules scattered all over the inner surface. Histopathology showed focal areas of thyroid tissue composed of acini filled with colloid, without any atypia (Figure 3). 

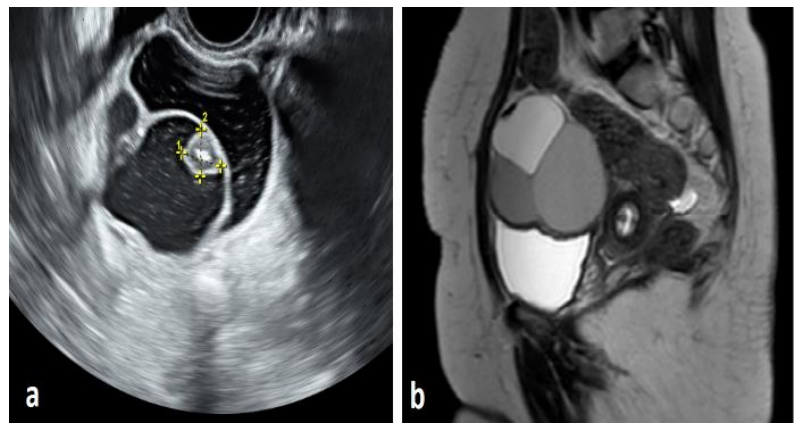

Figure 1: (a) USG -solid nodule seen in a loculus, (b) MRI- multiloculated cystic lesion in the right adnexa with thin internal septations.

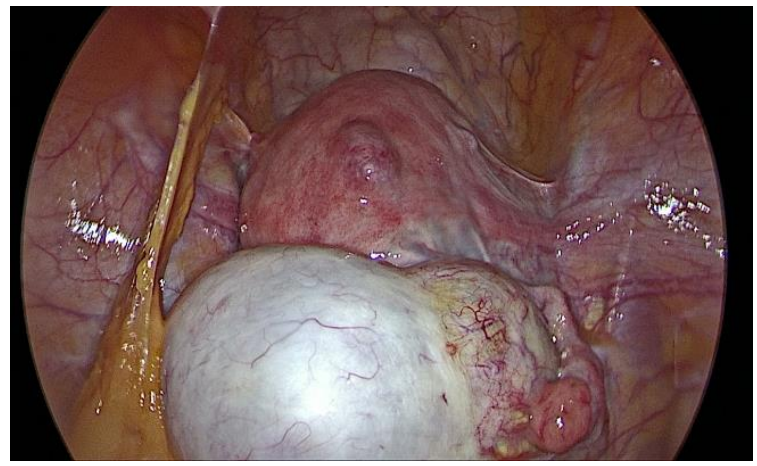

Figure 2: Laparoscopy showing a right ovarian multiloculated cyst.

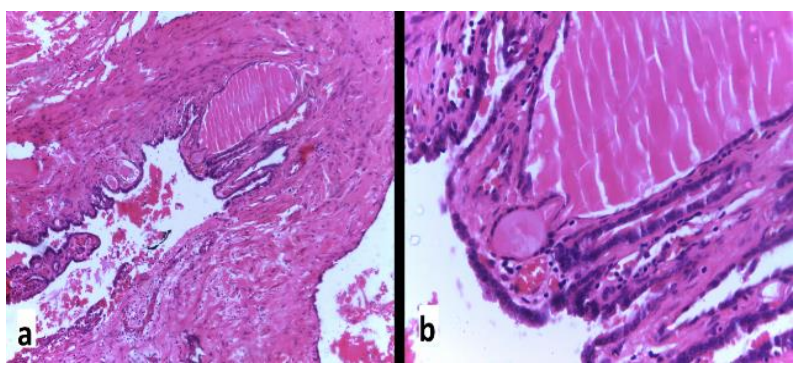

Figure 3: Focal areas showing thyroid tissue composed of acini filled with colloid (a) 10X, (b) 40X.

The postoperative course was uneventful, and the patient was discharged from the hospital on the first postoperative day. On two months follow up, there were no complaints and ultrasonography were unremarkable.

\section{DISCUSSION}

Struma ovarii is a rare ovarian tumour. Although about $15 \%$ of all ovarian teratomas contain one or more foci of thyroid tissue, only 3-5\% has thyroid tissue occupying more than $50 \%$ of the tumor mass, qualifying for the diagnosis of struma ovarii. ${ }^{5}$ Malignant struma ovarii are found in $0.3 \%$ of teratomas. ${ }^{3}$ Malignant struma ovarii is frequently associated with follicular variants of papillary thyroid carcinoma (54\%) and papillary thyroid carcinoma $(21 \%)^{4}$
Like any other ovarian tumor, Struma ovarii presents with non-specific symptoms like lower abdominal pain, abdominal mass and frequent urination. ${ }^{2}$ Although the name "struma ovarii" literally means ovarian thyroid, only about $5-8 \%$ of patients present with clinical hyperthyroidism. ${ }^{1,6}$ About $17-33.3 \%$ of patients may present with ascites and hydrothorax, mimicking malignancy. ${ }^{1}$ Imaging studies are non-specific and mostly show unilateral tumors, mixed cystic and solid mass, unilocular or multilocular cyst with clear margins. ${ }^{7}$ Serum CA-125 measurements are of little value in diagnosis. Pre-operative diagnosis is challenging due to its rarity and non-specific clinical and imaging features.

The differential diagnosis includes mucinous or serous ovarian cystadenoma, mature cystic teratoma without fatty tissue, ovarian cancer, endometriosis and tuboovarian abscess.

In this case, a 41-year-old lady, with one previous cesarean section presented with complaints of pain abdomen and dysmenorrhoea. Her ultrasonography and MRI both suggested a cystadenoma with a solid component.

The management of struma ovarii depends on various factors including age, desire for fertility, size of the tumor, whether benign or malignant and peritoneal metastasis. ${ }^{8}$ Unilateral struma ovarii in the reproductive age group is usually treated by unilateral adnexectomy, while total hysterectomy with bilateral salpingooophorectomy is recommended for bilateral tumors and in postmenopausal women. ${ }^{9}$

The final diagnosis is made by histopathology, which shows the presence of thyroid follicles of various sizes. After surgical management, the prognosis of benign disease and malignant cases without metastases is good. Malignant struma ovarii found on histopathology need to be treated like any other ovarian malignancy, with or without thyroidectomy and adjuvant therapy including I131 therapy. ${ }^{10}$ Long-term follow-ups in malignant cases is required due to the risk of recurrence. ${ }^{1}$

\section{CONCLUSION}

Struma ovarii is challenging to diagnose due to diverse clinical manifestations and imaging studies. Most of these cases are benign and unilateral adnexectomy is sufficient. Patients should be counseled for follow up.

\section{Funding: No funding sources \\ Conflict of interest: None declared \\ Ethical approval: Not required}

\section{REFERENCES}

1. Ting Z, Pingping C, Yuping G. Struma ovarii: a mini review. Int J Clin Exp Med. 2018;11(10):10364-71. 
2. Binti Md Nor N, Kusumoto T, Inoue S, Nakamura K, Seki N, Hongo A, et al. Three cases of struma ovarii underwent laparoscopic surgery with definite preoperative diagnosis. Acta Medica Okayama. 2013;67(3):191-5.

3. Rosenblum NG, LiVolsi VA, Edmonds PR, Mikuta JJ. Malignant struma ovarii. Gynecol Oncol 1989;32:224-7.

4. Goffredo P, Sawka AM, Pura J, Adam MA, Roman SA, Sosa JA. Malignant struma ovarii: a populationlevel analysis of a large series of 68 patients. Thyroid. 2015;25(2):211-5.

5. Khediri Z, Mbarki C, Ben Abdelaziz A, Hsayoui N, Mezghenni S, Oueslati. Struma Ovarii: Clinical presentation of an uncommon tumor. Int J Case Rep Ima. 2012;4:10-4.

6. Teale E, Gouldesbrough DR, Peacey SR. Graves' disease and coexisting struma ovarii: struma expression of thyrotropin receptors and the presence of thyrotropin receptor stimulating antibodies. Thyroid. 2006;16:791-3.
7. Savelli L, Testa AC, Timmerman D, Paladini D, Ljungberg O, Valentin L. Imaging of gynecological disease: clinical and ultrasound characteristics of struma ovarii. Ultrasound Obstet Gynecol. 2008;32:210-9.

8. Marti JL, Clark VE, Harper H, Chhieng DC, Sosa JA, Roman SA. Optimal surgical management of well differentiated thyroid cancer arising in Struma ovarii: a series of 4 patients and a review of 53 reported cases. Thyroid. 2012;22(4):400-6.

9. Shrimali RK, Shaikh G, Reed NS. Malignant struma ovarii: the west of Scotland experience and review of literature with focus on postoperative management. J Med Imaging Radiation Oncol. 2012;56(4):478-82.

10. Yücesoy G, Cakiroglu Y, Muezzinoglu B, Besnili B, Yucesoy I. Malignant struma ovarii: a case report. J Korean Med Sci. 2010;25(2):327-9.

Cite this article as: Paul PG, Annal A, Chowdary KA, Paul G, Shilotri M. A case benign struma ovarii. Int J Reprod Contracept Obstet Gynecol 2021;10:1224-6. 